\title{
Metabolic and production responses in dairy cows fed peas or rapeseed meal on grass silage based diet
}

\author{
A.Vanhatalo ${ }^{1}$, S. Ahvenjärvi and S. Jaakkola \\ MTT, Agrifood Research Finland, Animal Production Research \\ FIN-31600 Jokioinen, Finland
}

\begin{abstract}
A $4 \times 4$ Latin square was conducted with four rumen cannulated cows to investigate responses to isonitrogenous supplementation of grass silage-cereal diet with rapeseed meal (RSM) or peas supplied either dried or ensiled. Omasal canal flow measurements showed that protein supplements increased non-ammonia $\mathrm{N}$ flow to the intestine, though pea supplements less than RSM. Plasma concentrations of branched chain and essential amino acids were also increased by both RSM and pea supplements. All protein supplements increased yields of milk and milk constituents compared to control, but these increases seemed to be less with peas than with RSM.
\end{abstract}

KEY WORDS: peas, rapeseed, dairy cow, non-ammonia-N flow, amino acids

\section{INTRODUCTION}

Use of home-grown protein sources in dairy cow feeding has been brought into focus as a consequense of BSE crisis and the dominance of genetically modified soyabean meal on the market. Field peas (Pisum sativum L.) are a potential alternative to provide locally produced protein feed for livestock in EU.

It has been shown that soyabean meal (SBM) can be completely substituted by peas as the protein source for high-yielding dairy cows consuming grass silage based diets without any adverse effect on production (Petit et al., 1997). Peas have also succesfully substituted for rapeseed meal (RSM) on grass silage diet (Heikkilä and Toivonen, 2003), although in some cases peas have impaired milk production when RSM has been completely replaced with peas (Khalili et al.,

\footnotetext{
${ }^{1}$ Corresponding author: e-mail: aila.vanhatalo@helsinki.fi

${ }^{1}$ Present address: Department of Animal Science, University of Helsinki, P.O.Box 28, 00014

University of Helsinki, Finland
} 
2002). Peas have relatively high protein and starch contents, which both may contribute to reasonable production responses obtained with peas.

The aim of the present study was to examine metabolic and production responses of cows to supplementation of grass silage-cereal diet with peas. As rapeseed protein proved to be more efficiently used than that of SBM on grass silage diets (Shingfield et al., 2003), RSM was used as a positive control.

\section{MATERIAL AND METHODS}

Four rumen cannulated Finnish Ayrshire cows 9-13 weeks in their 2.-4. lactation were used in the experiment designed as a $4 \times 4$ Latin square with 21-d periods. The control diet (C) consisted of formic acid preserved grass silage offered $a d$ libitum (metabolizable energy $11.1 \mathrm{MJ} / \mathrm{kg}$ dry matter (DM), crude protein (CP) $160 \mathrm{~g} / \mathrm{kg} \mathrm{DM}$ ) and concentrate mixture (CP $129 \mathrm{~g} / \mathrm{kg} \mathrm{DM}$; barley, oats and sugar beet pulp) given at a rate of $10 \mathrm{~kg} / \mathrm{d}$. During the collection period grass silage DM intake was restricted to $95 \%$ of the adaptation period intake. On the other three diets a portion of the barley in the concentrate was isonitrogenously replaced with RSM, dry peas (DP) or ensiled crimped pea (EP) (concentrate CP on an average $179 \mathrm{~g} / \mathrm{kg} \mathrm{DM}$ ). Ensiled crimped pea was prepared by passing peas through a roller mill and ensiling with formic acid additive at a rate of $3 \mathrm{~L} / \mathrm{t}$. Feed intake and milk yield of cows were recorded daily. Omasal sampling and triple marker techniques were used to assess nutrient flow entering the omasal canal of cows (Ahvenjärvi et al., 1999). Blood from the tail vein was sampled three times during the feeding cycle on the last day of the experimental period.

\section{RESULTS}

Grass silage was of high fermentation quality (pH 4.0, DM $279 \mathrm{~g} / \mathrm{kg}$, lactic acid (LA) $71 \mathrm{~g} / \mathrm{kg} \mathrm{DM}$, water soluble carbohydrates (WSC) $18 \mathrm{~g} / \mathrm{kg} \mathrm{DM}$, and ammonium-N $43 \mathrm{~g} / \mathrm{kg} \mathrm{N}$ ), as was also ensiled crimped pea (pH 5.2, DM 643 g/kg, LA 6 g/kg DM, WSC 73 g/kg DM, and ammonium-N 17 g/kg N). Protein supplementation increased grass silage DM intake and yields of milk, energy corrected milk (ECM), fat, protein and lactose, while no significant $(\mathrm{P}>0.05)$ differences were found between the protein supplemented diets in these parameters (Table 1). Omasal canal non-ammonia-N (NAN) flow and ruminal $\mathrm{N}$ absorption increased with protein supplementation, increases in NAN flow being higher and in ruminal $\mathrm{N}$ absorption lower with RSM than with peas. Apparent digestibility of organic matter $(\mathrm{OM})$ in the rumen and in the total tract were also increased owing to protein supplementation, increases being, however, higher with pea treatments than with RSM. 
Table 1. Feed intake, milk production, $\mathrm{N}$ parameters, nutrient digestibility and blood metabolites

\begin{tabular}{|c|c|c|c|c|c|c|c|c|}
\hline \multirow{2}{*}{ Item } & \multicolumn{4}{|c|}{ Diet } & \multirow{2}{*}{$\mathrm{SEM}^{2}$} & \multicolumn{3}{|c|}{ Orthogonal contrasts $^{1}$} \\
\hline & $\mathrm{C}$ & RSM & DP & EP & & $\mathrm{C}_{1}$ & $\mathrm{C}_{2}$ & $\mathrm{C}_{3}$ \\
\hline \multicolumn{9}{|l|}{ DM intake, $\mathrm{kg} / \mathrm{d}$} \\
\hline total & 18.1 & 20.0 & 19.0 & 19.7 & 0.66 & 0.10 & 0.44 & 0.45 \\
\hline \multicolumn{9}{|l|}{ Production, $\mathrm{kg} / \mathrm{d}$} \\
\hline milk & 24.9 & 28.7 & 26.9 & 27.9 & 1.14 & 0.07 & 0.40 & 0.54 \\
\hline ECM & 25.6 & 29.7 & 28.4 & 28.1 & 0.78 & 0.01 & 0.19 & 0.78 \\
\hline fat & 1.04 & 1.21 & 1.18 & 1.12 & 0.041 & 0.04 & 0.27 & 0.34 \\
\hline protein & 0.82 & 0.96 & 0.90 & 0.92 & 0.038 & 0.05 & 0.36 & 0.74 \\
\hline lactose & 1.22 & 1.40 & 1.32 & 1.37 & 0.056 & 0.06 & 0.42 & 0.56 \\
\hline \multicolumn{9}{|l|}{$N$ parameters, $g / d$} \\
\hline $\mathrm{N}$ intake & 425 & 535 & 507 & 527 & 17.5 & $<0.01$ & 0.44 & 0.46 \\
\hline omasal NAN flow & 411 & 480 & 435 & 433 & 15.4 & 0.08 & 0.05 & 0.91 \\
\hline ruminal absorption & 15 & 57 & 73 & 95 & 4.9 & $<0.01$ & 0.01 & 0.02 \\
\hline in faeces & 130 & 148 & 138 & 145 & 6.7 & 0.13 & 0.43 & 0.45 \\
\hline in urine & 148 & 200 & 196 & 203 & 5.7 & $<0.01$ & 0.98 & 0.41 \\
\hline \multicolumn{9}{|l|}{ OM digestibility, $\mathrm{g} / \mathrm{kg}$} \\
\hline in the rumen & 560 & 570 & 590 & 612 & 4.1 & $<0.01$ & 0.01 & 0.01 \\
\hline in the total tract & 753 & 759 & 769 & 773 & 4.1 & 0.02 & 0.05 & 0.51 \\
\hline \multicolumn{9}{|l|}{ Blood metabolites, $\mathrm{Mm}$} \\
\hline acetate & 1.09 & 1.08 & 1.06 & 1.24 & 0.051 & 0.52 & 0.34 & 0.05 \\
\hline BHB & 0.73 & 0.76 & 0.80 & 1.02 & 0.065 & 0.12 & 0.11 & 0.06 \\
\hline urea & 2.93 & 4.00 & 4.15 & 4.18 & 0.126 & $<0.01$ & 0.33 & 0.89 \\
\hline BCAA & 0.38 & 0.53 & 0.47 & 0.49 & 0.036 & 0.03 & 0.31 & 0.77 \\
\hline EAA & 0.73 & 0.96 & 0.90 & 0.88 & 0.064 & 0.05 & 0.41 & 0.95 \\
\hline NEAA & 1.04 & 1.11 & 1.13 & 1.12 & 0.056 & 0.29 & 0.81 & 0.94 \\
\hline
\end{tabular}

${ }^{1} \mathrm{C}_{1}=\mathrm{C}$ vs RSM $+\mathrm{DP}+\mathrm{EP}, \mathrm{C}_{2}=\mathrm{RSM}$ vs DP $+\mathrm{EP}$ and $\mathrm{C}_{3}=\mathrm{DP}$ vs EP

${ }^{2}$ standard error of the mean

Plasma non-esterified fatty acid or glucose concentrations were not affected by the dietary treatments (data not shown), but plasma acetate and ß-hydroxybutyrate (BHB) concentrations were higher for EP than for DP. Protein supplementation increased plasma urea, branched-chain amino acid (BCAA) and essential amino acid (EAA) concentrations, while no differences $(\mathrm{P}>0.05)$ were found between the protein supplemented diets in these parameters.

\section{DISCUSSION}

Increases in grass silage DM intakes and yields of milk and milk constituents due to protein supplementation were consistent with earlier studies (Khalili et al., 2002; Heikkilä and Toivonen, 2003). Despite lack of statistical differences 
between the protein supplements in milk production, RSM seemed to increase yields of milk and protein $(+3.8$ and $0.136 \mathrm{~kg} / \mathrm{d})$ more than DP $(+2.0$ and 0.081 $\mathrm{kg} / \mathrm{d})$ or EP $(+3.0$ and $0.100 \mathrm{~kg} / \mathrm{d})$ in line with results of Khalili et al. (2002). This is also supported by the higher omasal NAN flow and lower ruminal $\mathrm{N}$ absorption obtained with RSM as compared with pea treatments. Positive production responses with RSM have been attributed not only to increased silage DM intake but also to increased dietary NAN (Ahvenjärvi et al., 1999; Shingfield et al., 2003). This was probably not the case with peas, although inclusion of peas in the diet increased amino acid supply to the intestines as evidenced by enhanced concentrations of BCAA and EAA in plasma of cows fed peas. Increased supply of digestible $\mathrm{OM}$ for rumen microbes is a likely explanation for enhanced protein supply to the intestine with peas in the present study.

\section{CONCLUSIONS}

Increased supply of digestible OM for rumen microbes enhanced protein supply to the intestine with peas. Increased supply of metabolizable energy may largely explain production responses obtained with peas.

\section{REFERENCES}

Ahvenjärvi S., Vanhatalo A., Huhtanen P., Varvikko T., 1999. Effects of supplementation of a grass silage and barley diet with urea, rapeseed meal and heat-moisture-treated rapeseed cake on omasal digesta flow and milk production in lactating dairy cows. Acta Agr. Scand., Sect. A, Anim. Sci. 49, 179-189

Heikkilä T., Toivonen V., 2003. Pea or rapeseed meal as a protein supplement in milk production. In: O. Niemeläinen, M. Topi-Hulmi (Editors). Proceedings of the NJF's 22nd Congress 'Nordic Agriculture in Global Perspective', Turku (Finland). Jokioinen: MTT Agrifood Research Finland, NJF, p. 13

Khalili H., Kuusela E., Suvitie M., Huhtanen P., 2002. Effect of protein and energy supplements on milk production in organic farming. Anim. Feed Sci. Tech. 98, 103-119

Petit H.V., Rioux R., Ouellet D.R., 1997. Milk production and intake of lactating cows fed raw or extruded peas. J. Dairy Sci. 80, 3377-3385

Shingfield K., Vanhatalo A., Huhtanen P., 2003. Comparison of heat-treated rapeseed expeller and solvent-extracted soya-bean meal protein supplements for dairy cows given grass silage-based diets. Anim. Sci. 77, 305-317 